$<$ 短 報 $>$

\title{
地域医療機関と肝移植専門機関との連携： 患者紹介のタイミングに関するアンケート調査報告
}

\author{
山敷 宣代 ${ }^{12)}$ * 菅原 寧彦1)3 \\ 冨樫 順一 ${ }^{3)}$ 田中 智大 ${ }^{1)}$
}

はじめに : 2010 年 7 月に臟器移植法が改正されて以 降, 年間の脳死肝移植件数は年数件から約 40 件まで増 加し，登録を希望する患者数も増加している．しかし 移植医療機関に受診しても移植適応外であったり，脳 死肝移植待機リスト登録後に医学的・社会的な理由で ドロップアウトする事がある ${ }^{1)}$. 移植待機期間中には, 紹介元のかかりつけ医である地域の医療機関と移植医 療機関との間で治療方針等についての認識の一致が重 要となってくる. 地域医療機関との連携は, 移植医療 機関への患者紹介から始まる，しかしながら，移植医 療機関で適当と考えている移植適応や紹介の夕イミン グが, どの程度一般の医療機関に普及しているかは不 明な点も多い.そこで, 当院と関係のある地域医療機 関への意識調査を実施し，今後の対策について考察し た.

対象・方法：2003 年から 2011 年までに当院に肝移植 検討症例を紹介頂いた医療機関 (移植実施施設は除外) 252 施設を対象とし, 各施設につき 1 部アンケートを送 付し，無記名郵送方式での回答を依頼した. 2012 年 3 月末までに 103 施設 (40.8\%) からの回答を頂いた. ア ンケートは, 移植検討時期についての質問 5 項目, 情 報公開についての質問 2 項目，回答者背景を問う質問 5 項目の合計 12 項目で構成し, 数分で回答できる内容 とした.

結果：1）対象者挹よび回答者背景：

アンケート送付対象となった 252 施設からは, 9 年間

1) 東京大学医学部附属病院臟器移植医療部

2）国際医療福祉大学山王メディカルセンター消化器内 科

3) 東京大学医学部肝胆膵 - 人工臓器移植外科

*Corresponding author: nyamashiki-gi@umin.ac.jp <受付日2012年12月11日 ><採択日2013年1月15日 >
田村 純人 ${ }^{3)}$ 金子 順一 ${ }^{3)}$

國土 典宏 ${ }^{13)}$

の調査期間中にのべ 766 人の紹介があった. 一施設か らの当院への紹介患者数は 1 人 -22 人で, 平均 $( \pm \mathrm{SD})$ $3.0 \pm 3.2$ 人であった.

回答者の勤務施設規模は病院（病床数 100 499）が 最も多く $(53 \%)$, ついで 500 床以上の病院, 診療所 (7\%)，100 床までの病院 (2\%) であった．専門分野は 肝臓内科 $47 \%$, 消化器内科 $29 \%$, 消化器 - 肝臓外科 $9 \%$ の他に内科 $11 \%$ ，小児科 $4 \%$ であった. 臨床経験年数 については 20 年以上が $75 \%$ を占め, 11-20 年 (18\%), 10 年まで $(7 \%)$ がそれに次いだ。診療状況に関して, 回答者の外来における慢性肝疾患患者数を問う質問に 対し月 2 人〜 400 人とばらつきがあり, 年間ののべ患者 数は中央值 (IQR) で 960 (360-1920) 人であった. そ のうち肝移植を検討すべき症例は年間 2(1-4) 人 (Fig.

1)で, 外来で診察する全肝疾患患者に占める割合は 0.2 (0.08-0.42)\%であった.

2）移植適応判断のきっかけ：

移植適応の判断において Child 分類を $91 \%$ の医師が 参考にしていた（必ず参考にする；77\%，時々参考に する；14\%，参考にしない；9\%).一方, Child-PughTurcotte スコアは 80\%の医師に利用されていた(必ず 利用する； $61 \%$, 時々利用する； $19 \%$, 利用しない； 20\%). Child-Pugh Turcotte スコアを利用する場合, 概 ね何点で肝移植を検討するか訊ねたところ, 77 人の回 答を得た (Fig. 2). Child 分類 C に該当する 10 点以上 との回答が $76 \%$ を占めた.

どのような病態の場合に肝移植を検討するか尋ねた 項目では, 102 回答中 $79 （ 78 \%)$ が非代償性肝硬変に なった時としている，具体的には，腹水増加，肝性脳 症, 食道静脈瘤破裂, 肝細胞癌の診断などを契機に肝 移植を検討している.

次に The Model for End-stage Liver Disease(MELD) スコアの認知度については, MELD スコアを知ってい て利用したことがある $(37 \%)$ ，知っているが利用した ことがない $(39 \%)$, 知らない $(24 \%)$ との結果であっ 


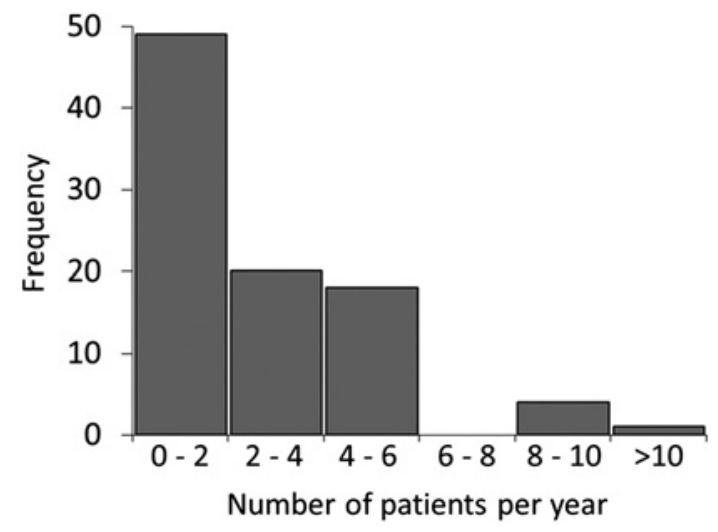

Fig. 1 Number of patients who were considered eligible for liver transplantation encountered at each referral outpatient clinics per year. Histogram shows that the majority of responders encounter as less as 2 such patients per each year.

た．知っているとの回答 $(n=78)$ のうち, 肝移植の適 応判断に MELD スコアを利用するかどうかの質問(使 用経験・将来の使用予定を問わない）に対しては, 利 用する $(51 \%)$, 利用しない $(8 \%)$, 無回答 $(17 \%)$ で あった。

3）情報公開 :

肝移植の適応基準についての情報公開がされている という実感がありますか？という質問に対し選択式(複 数選択可) および自由記載形式で回答を得た。学会専 門誌等で知っている $(52 \%)$, 学会ホームページ等で知っ ている $(28 \%)$ といった回答の一方で,「移殖施設によっ て異なるので困る」，「十分な情報が公開されていない」, 「脳死肝移植の待機リスト登録の手順や費用が分からな い」,「脳死からの臓器提供の順番が公開されていない」, などのコメントが見られた。

考察：アンケート回答者の多くは消化器・肝臟領域 を専門とする内科・外科医であり，平素から多数の慢 性肝疾患患者を診療していた，今回アンケート送付対 象とした施設全体では， 1 施設につき 9 年間に平均 3.0 人, 年平均にして 0.34 人の移植検討例の紹介があった. アンケートは無記名回答方式をとったため, 具体的に どの医療機関からの回答かは把握できない，しかし， アンケート調査によると肝移植を検討すべき症例数は 1 施設につき年間 2 $(1-4)$ 人であり，今回の結果は移 植医療への理解が深い医師の回答に偏って導かれた可

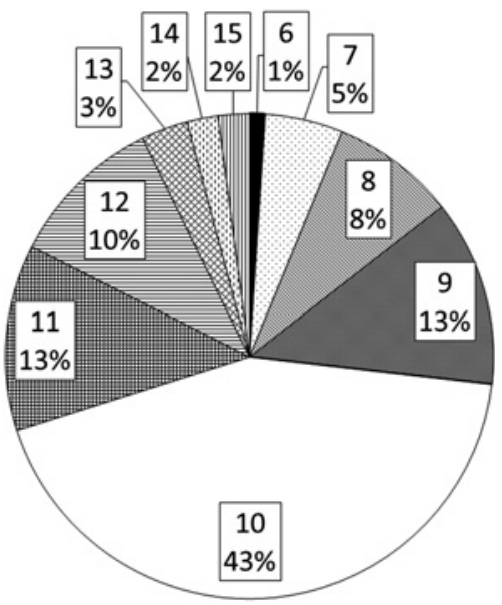

Fig. 2 Child-Pugh-Turcotte (CPT) scores at which point primary care physicians consider referring patients to transplant center. Numbers in the box indicate the CPT score and frequency (\%).

能性がある. しかしそのような母集団ということを考 慮しても，実際移植検討の対象と思われる症例は診療 患者全体の $0.2 \%$ 程度 (年に 2 症例程度) という結果で あった。

生体肝移植を中心に発展した我が国では，レシピエ ントおよびドナーの手術適応検討から術後の管理まで 外科医が主体的に診療に関わるため, 消化器肝臟内科 医が移植医療を術前から術後まで継続して診療する機 会は多くはない．移植実施件数もここ数年横ばいであ り, 消化器肝臓内科医にとって移植医療はまだ身近な ものにはなっていない現状が伺える。一方肝臓移植手 術件数の多い米国では移植肝臓内科学 (Transplant hepatology) という専門領域が確立し, また消化器内科の 後期研修の一環としても移植医療に一定期間携わるこ とが多い22.

今回, 移植を検討する時期についての質問では, Child 分類を参考にし, 腹水, 食道静脈瘤, 肝硬変といった, 一般的な移植適応時期と考えられている報告に一致し， おおむね妥当な夕イミングと考えられる ${ }^{3)}$. しかしなが ら, Child-Pugh-Turcotte スコアで 10 以上になってから 移植を検討するとの回答が大半を占めていたことから は, “too sick to transplant”となったタイミングでの紹 介例に懸念が残る ${ }^{4}$. 肝不全が進行し全身状態不良となっ てからの紹介の場合, 肝機能の観点からは移植適応が あるとしても, 多臟器不全等の合併のため手術適応外 
となるか，あるいは周術期死亡リスクが上昇し良好な 術後成績が望めないからである。移植医療について説 明を受けた患者さんはこれから受ける手術の大きさや リスク，生活などの現実に直面し，手術を受けるかど うかについて時間をかけて検討されることも多い. 肝 不全の状態となる前に, 移植医療について検討する機 会が持てることが望ましいのではないだろうか.

今回のアンケート調査では MELD スコアを必ず使用 するとする回答は限られていた. MELD スコアは総ビ リルビン, INR, クレアチニンの三項目を用いた式から 導かれる ${ }^{5}$. 未期肝疾患の短期 (3 力月後) 予後予測因 子として報告され，その後多くの報告で末期肝疾患患 者の予後予測因子としての妥当性が確認されてきた.

日本の脳死肝移植の優先順位決定においては MELD スコアは用いられていないが, 医学的緊急度決定の参 考とされている，その客観性や簡便さから今後利用さ れる可能性は高く, 消化器病を専門とする医師に周知 の機会があっても良いのではないかと思われた．

まとめ: 今回のアンケート調查結果から, 消化器 · 肝臓専門医が日常的に診療する外来患者のうち肝臓移 植を検討する場面はごく限られているという現状が明 らかとなった．移植実施施設からは，今後も移植適応 や制度について分かりやすい情報発信を継続するとと もに, 一般の消化器肝臓内科医が移植医療を経験でき るような制度作りも今後期待される.

謝辞 : 本アンケートにご協力いただきました関東界隈 252 施設打よび担当の先生方に深謝いたします. 無記名郵送方式 といたしましたため, 施設名, 担当者名の記載は省略させて いただきます。

本研究は, MEXT 科研費, 基盤研究 (C) 23590963 の助 成を受けたものです.

索引用語：Child-Pugh-Turcotte スコア, MELD スコア, 移植適応評価

文献：1）山敷宣代, 菅原寧彦, 田村純人, 他. 肝 臟 2009；50：634-643 2) 山敷宣代, 菅原寧彦, 小池和彦, 他. 外科 $2011 ; 73: 1155-1159$

3) Murray KF, Carithers RL Jr. Hepatology 2005; 41: 1407-1432 4) Merion RM. Liver Transplant 2004; 10: S69-S73 5) Kamath PS, Wiesner RH, Malinchoc M, et al. Hepatology 2001; 33: 464—470

\section{英文要旨}

Cooperation with community-based hospital and liver transplant program: a regional questionnaire-based survey on referring indications

Noriyo Yamashiki ${ }^{12) *}$, Yasuhiko Sugawara ${ }^{13)}$, Sumihito Tamura ${ }^{3}$, Junichi Kaneko ${ }^{3}$, Junichi Togashi ${ }^{3}$, Tomohiro Tanaka ${ }^{1)}$, Norihiro Kokudo ${ }^{1 / 3)}$

We conducted a questionnaire-based survey on referral indications for liver transplantation. Questionnaire was sent to each regional clinics/hospitals that has referred at least one liver transplant candidate to our institution in the past. Two hundred and fifty-two such clinics/hospitals were identified. Among them, 103 $(40.8 \%)$ returned their responses. The majority were hepatologists $(47 \%)$, followed by gastroenterologists $(29 \%)$ and surgeons (18\%). Responders mainly dealt with chronic liver diseases, with a median volume (IQR) of 960 (360-1920) outpatient clinic visits per year. However, as less as two patients per year who may be considered indicated for liver transplantation were encountered in average. Seventy-six percent felt that Child-Pugh-Turcotte score $\geqq 10$ was threshold for referral. This survey revealed that opportunity for primary physicians to experience patients eligible for liver transplantation may be very much limited. Continuing effort is necessary to disseminate practical clinical knowledge on liver transplantation to hepatogastroenteorlogy specialists in Japan.

Key words: Child-Pugh-Turcotte score, MELD score, patient selection

Kanzo 2013; 54: 211-213

1) Organ Transplantation Service, The University of Tokyo Hospital, Tokyo, Japan

2) Department of Gastroenterology, Sanno Medical Center, International University of Health and Welfare, Tokyo, Japan

3) The Artificial Organ and Transplantation Division, Department of Surgery, The University of Tokyo Hospital, Tokyo, Japan

*Corresponding author: nyamashiki-gi@umin.ac.jp 